\title{
Analysis of growth and feed conversion in purebred and crossbred German Merinolandschaf lambs
}

\author{
K. F. Schiller, V. Grams, and J. Bennewitz \\ Institute of Animal Science, University of Hohenheim, Stuttgart, Germany \\ Correspondence to: K. F. Schiller (katja.schiller@uni-hohenheim.de)
}

Received: 2 June 2014 - Accepted: 10 September 2014 - Published: 29 April 2015

\begin{abstract}
In this study, ewes of "Merinolandschaf", a breed widespread in southern Germany, were crossed with rams of five meat breed types (Ile de France, Charollais, German black-headed mutton sheep (Deutsches Schwarzköpfiges Fleischschaf), Suffolk, Texel) and Merinolandschaf rams. The resulting lambs (179 individuals) were fattened intensively from 55.3 days and body weight of $20.4 \mathrm{~kg}$ until 121.7 days and a weight of $40.9 \mathrm{~kg}$. While fattening, feed intake was recorded and lambs were weighed weekly. Ile de France $\times$ Merinolandschaf and Texel $\times$ Merinolandschaf seem to be of greatest economic interest for intensive fattening because they showed the best feed conversion rate and energetic feed conversion rate. Only these crosses were significantly superior compared to purebred Merinolandschaf in feed conversion rate and also in daily body weight gain during the fattening period. Except Charollais $\times$ Merinolandschaf, all crosses showed at least a tendency of improvement in all three traits compared to Merinolandschaf, although this is not always significant. This underlines the advantage of one-way cross-breeding for efficiently producing lamb meat. The growth was modelled with a linear model and the Gompertz model. The results showed that both models fit the data well, although the average $R^{2}$ was slightly higher and the average mean square error was slightly lower for the Gompertz model. In addition, the use of the Gompertz model provided some interesting biological insights concerning the growth of lambs and differences between the crosses, even though the lambs were slaughtered before reaching their mature body weight.
\end{abstract}

\section{Introduction}

The "Merinolandschaf" (ML) is a typical widespread breed of sheep in southern Germany. Sheep of this breed are completely white, polled, with a wooled forehead and broad hanging ears. Body weight (BW) for adult is $80-90 \mathrm{~kg}$ for ewes and $120-140 \mathrm{~kg}$ for rams. These sheep have aseasonal reproduction and good fertility. This breed was originally developed by crossing Merino sheep imported from Spain with local breeds with the intent of breeding robust sheep able to travel the summer to winter pastures routes but also which deliver improved wool quality (Sambraus, 2011).

However, due to the currently high costs for shearing and low wool prices, lamb meat production is an important source of income from sheep (Strittmatter, 2005). In order to improve the growth performance of fattening lambs, ML dams are frequently mated with a meat breed type sire to obtain F1 hybrid progeny. Naturally, the choice of the sire line is of fundamental importance for optimising this oneway crossing system. In a previous study, five sire breeds were tested for their ability to produce high-quality F1 hybrid lambs (Henseler et al., 2014a, b). However, the important trait feed conversion rate was not considered in that study.

Growth can be described by a single parameter, e.g. daily body weight gain (DG). However, the trajectory of growth over the entire lifetime might be of interest as well. Different models have been used from different authors for modelling growth of sheep. As an example, Daskiran et al. (2010) used Gompertz, Bertalanffy, Brody, logistic and negative exponential models, and Lambe et al. (2006) used Gompertz, Richards, exponential and logistic models. Growth models are usually able to summarise the pattern of growth in two to four parameters. Lambe et al. (2006) investigated several growth models to describe the growth of lambs. Among the models tested, the Gompertz model fit the data best. Addi- 
tionally these authors have shown genetic variability within and between breeds and discussed the use of this variability for breeding purposes.

The aim of the present study was to investigate the ability of six sire breeds to produce F1 hybrid lambs with ML. The two important traits, DG and feed conversion rate (FCR), were considered. A further aim was to fit growth curves and to compare growth model parameters among the F1 hybrids.

\section{Material and methods}

\subsection{Animals, feed and management}

The experiment took place at the Oberer Lindenhof experimental station (moderate climate, $600 \mathrm{~m}$ above sea level, annual rainfall $752 \mathrm{~mm}$ ) of the University of Hohenheim, Germany. In total 134 ML ewes were crossed with rams of six breeds: Charollais, Ile de France, German black-headed mutton sheep (Deutsches Schwarzköpfiges Fleischschaf), Suffolk, Texel and ML. Each sire breed was represented by one ram. The ram was progeny tested in an earlier study with around 50 progeny produced with ML ewes (Henseler et al., 2014a). The average progeny yield for DG and other growth and meat traits of the selected rams was close to the mean of the respective breed. Hence, it is assumed that the selected rams are a representative sample of their breeds. Unfortunately it was not possible to include multiple rams per sire breed because there were no additional progeny-tested sires available.

The number of lambs as well as number of singletons and males per cross is shown in Table 1. Lambs were born in July and August 2012. During the fattening period, lambs were weighed weekly. Lambs were fed with hay (daily 200-300 $\mathrm{g}$ animal $^{-1}$, $7 \mathrm{MJ}$ ME (metabolisable energy) and $63 \mathrm{~g} \mathrm{~kg}^{-1} \mathrm{CP}$ (crude protein)) and concentrate (11 MJ ME and $188 \mathrm{~g} \mathrm{~kg}^{-1} \mathrm{CP}$ ) ad libitum. Total feed intake of hay and of concentrate, and the sum of both, were determined. Due to limited space, six lambs from each F1 hybrid were housed in individual pens and the remaining lambs were housed in groups of 17 to 30 individuals. Lambs were slaughtered when reaching a finishing weight of approximately $41 \mathrm{~kg} \mathrm{BW}$.

\subsection{Statistical analysis}

Daily body weight gain over the lifetime $\left(\mathrm{DG}_{\mathrm{L}}\right)$ and during the fattening period $\left(\mathrm{DG}_{\mathrm{F}}\right)$ were recorded for each lamb and were analysed using the following statistical model:

$y_{i j k m l}=\mu+\mathrm{SB}_{j}+\mathrm{BT}_{k}+\mathrm{SEX}_{l}+\operatorname{dam}_{m}+e_{i j k l m}$,

where $y_{i j k m l}$ is the trait record of lamb $i(\mathrm{~kg}), \mathrm{SB}_{j}$ is the fixed effect of sire breed $j, \mathrm{BT}_{k}$ and $\mathrm{SEX}_{l}$ are the fixed effects of birth type $k$ (single or twin) and of sex $l$, respectively, and $\operatorname{dam}_{m}$ is the random effect of the dam. The dams were assumed to be unrelated. The model was fitted using the MIXED procedure of SAS (9.2, SAS Institute, Inc., Cary,
NC, USA). The feed conversion rate traits (FCR, kg dry matter (DM) feed intake $\mathrm{kg}^{-1} \mathrm{G}_{\mathrm{F}}$ ) and energetic FCR (eFCR, $\mathrm{MJ} \mathrm{kg}^{-1} \mathrm{DG}_{\mathrm{F}}$ ) were analysed as follows. The means of the F1 hybrid were calculated from the corresponding group means and the variances were calculated from the trait values of the six lambs housed in the individual pens. The standard errors of the group means were approximated using these two parameters and the number of lambs in the groups. This way of estimating the standard errors was chosen because only six lambs per cross could be housed in individual pens and the remaining lambs had to be housed in groups. Differences between the means of the F1 hybrids were tested for significance using the Welch test.

Two types of growth curves were fitted to the weight records. The first one is the Gompertz model, for which the notation of Lambe et al. (2006) was used.

$y(t)=A \exp \left[-\exp \left(B e \frac{C-t}{A}\right)\right]$,

where $t$ is the age in days when the weight $y(\mathrm{~kg})$ was recorded, $A$ is the estimated mature body weight $(\mathrm{kg}), B$ is the maximum DG $(\mathrm{kg}), C$ is the age at maximum $\mathrm{DG}_{\mathrm{F}}$ (days) and $e$ denotes the Euler number. The second model is a linear model,

$y(t)=\mathrm{INT}+b t$,

where $b$ is the average DG $(\mathrm{kg})$ and INT is the birth weight $(\mathrm{kg})$. The growth curves were fitted to the data of each individual using the NLIN procedure of SAS version 9.2. This resulted in three parameter estimates and their standard errors for the Gompertz model and two for the linear model for each lamb. The fit of the two models was analysed by calculating the mean square errors and the $R^{2}$ values for each lamb and then averaged over all lambs. The parameter $(A$, $B, C$, INT and $b$ ) estimates were analysed using model (1), but using the reciprocal of the error variance of the estimated parameters (i.e. standard error squared) as weighting factors to ensure that individuals with more repeated measurements and hence lower standard errors where weighted stronger.

\section{Results}

\subsection{Descriptive statistics of observations}

The average birth weights are shown in Table 1. TX $($ Texel $\times$ ML) showed the highest birth weight, and IF (Ile de France $\times$ ML) and SK (German black-headed mutton sheep $\times$ ML) the lowest. Weaning BW, weaning age, BW and age at finishing are shown in Table 1 . Weaning BW was at a similar level for all crosses. The same holds true for finishing BW. More variability can be observed in the age at finishing. The highest age was observed for $\mathrm{CH}$ (Charollais $\times$ ML), ML and SU (Suffolk $\times$ ML) and the lowest for IF, with a difference between them of around 15 days. 
Table 1. Crosses of sheep breeds, number of lambs and means and standard deviation of birth weight, bodyweight and age at weaning and finishing of fattening lambs.

\begin{tabular}{|c|c|c|c|c|c|c|c|c|c|c|c|c|c|c|}
\hline \multirow[b]{2}{*}{ Cross } & \multirow[b]{2}{*}{$\mathrm{Abb}$} & \multirow[b]{2}{*}{$N$} & \multirow[b]{2}{*}{$N$ male } & \multirow[b]{2}{*}{$N$ single } & \multicolumn{2}{|c|}{$\begin{array}{l}\text { Birth } \\
\text { BW, kg }\end{array}$} & \multicolumn{2}{|c|}{$\begin{array}{l}\text { Weaning } \\
\mathrm{BW}, \mathrm{kg}\end{array}$} & \multicolumn{2}{|c|}{$\begin{array}{l}\text { Weaning } \\
\text { age, days }\end{array}$} & \multicolumn{2}{|c|}{$\begin{array}{c}\text { Finishing } \\
\text { BW, kg }\end{array}$} & \multicolumn{2}{|c|}{$\begin{array}{l}\text { Finishing } \\
\text { age, days }\end{array}$} \\
\hline & & & & & Mean & SD & Mean & SD & Mean & SD & Mean & SD & Mean & SD \\
\hline Charollais $\times$ ML & $\mathrm{CH}$ & 35 & 13 & 16 & 5.2 & 0.8 & 20.7 & 3.3 & 53.9 & 6.9 & 40.7 & 1.6 & 125.6 & 18.9 \\
\hline Ile de France $\times$ ML & IF & 23 & 10 & 7 & 5.0 & 1.1 & 20.3 & 3.3 & 51.3 & 8.5 & 41.2 & 3.2 & 110.8 & 16.0 \\
\hline $\mathrm{ML} \times \mathrm{ML}$ & ML & 36 & 19 & 18 & 5.3 & 0.8 & 20.7 & 3.4 & 56.0 & 7.9 & 40.9 & 1.6 & 125.6 & 18.0 \\
\hline $\begin{array}{l}\text { German black-headed } \\
\text { mutton sheep } \times \text { ML }\end{array}$ & SK & 25 & 12 & 6 & 5.0 & 0.7 & 20.1 & 3.3 & 56.8 & 7.8 & 40.8 & 1.4 & 122.0 & 15.9 \\
\hline Suffolk $\times$ ML & SU & 36 & 11 & 9 & 5.1 & 1.0 & 19.6 & 2.7 & 57.2 & 9.4 & 40.7 & 1.3 & 125.9 & 19.7 \\
\hline Texel × ML & $\mathrm{TX}$ & 24 & 12 & 10 & 6.0 & 1.0 & 21.2 & 4.2 & 55.6 & 10.3 & 40.9 & 2.1 & 114.2 & 21.6 \\
\hline
\end{tabular}

Table 2. Effect of cross on daily feed intake ( $\mathrm{g}$ ) of hay, concentrate and sum of both during the fattening period of lambs.

\begin{tabular}{lll|ll|ll}
\hline \multirow{2}{*}{ Cross } & \multicolumn{2}{c|}{ Hay } & \multicolumn{2}{|c|}{ Concentrate } & \multicolumn{2}{c}{$\begin{array}{c}\text { Hay }+ \\
\text { concentrate }\end{array}$} \\
\cline { 2 - 7 } & Mean & SE & Mean & SE & Mean & SE \\
\hline CH & $246^{\mathrm{a}}$ & 7 & $1418^{\mathrm{c}}$ & 9 & $1664^{\mathrm{c}}$ & 15 \\
$\mathrm{IF}$ & $241^{\mathrm{a}}$ & 10 & $1475^{\mathrm{d}}$ & 21 & $1715^{\mathrm{d}}$ & 22 \\
ML & $298^{\mathrm{b}}$ & 11 & $1246^{\mathrm{a}}$ & 28 & $1543^{\mathrm{a}}$ & 24 \\
SK & $249^{\mathrm{a}}$ & 15 & $1327^{\mathrm{ab}}$ & 30 & $1575^{\mathrm{ab}}$ & 27 \\
SU & $309^{\mathrm{b}}$ & 11 & $1291^{\mathrm{ab}}$ & 26 & $1601^{\mathrm{abc}}$ & 30 \\
TX & $293^{\mathrm{b}}$ & 10 & $1330^{\mathrm{b}}$ & 15 & $1623^{\mathrm{b}}$ & 15 \\
\hline
\end{tabular}

abcd Within a column, values with different superscript letters (a-d) differ significantly at $P \leq 0.05$.

\subsection{Feed conversion and growth performance}

The feed intake means are shown in Table 2. They varied significantly across the crosses for all three components considered (hay, concentrate and total). The highest (lowest) total feed consumption was observed for IF (ML). The feed conversion rates are shown in Table 3. Both FCR and eFCR varied significantly across the crosses. The lowest FCR was determined for IF and TX (4.5) and the highest for $\mathrm{CH}$ (5.5). The eFCR was found to be the lowest for TX (50.7) but without a significant difference from IF; the highest was found for $\mathrm{CH}$ (63.2). The least square means of $\mathrm{DG}_{\mathrm{F}}$ and $\mathrm{DG}_{\mathrm{L}}$ are shown in Table $3 . \mathrm{DG}_{\mathrm{F}}$ is consistently above $\mathrm{DG}_{\mathrm{L}}$, except for $\mathrm{CH}$. The daily body weight gain during the fattening period and $\mathrm{DG}_{\mathrm{L}}$ varied significantly across the crosses. The lowest values were observed for $\mathrm{CH}$ and $\mathrm{ML}$ and the highest for IF, though for all three crosses, differences from other crosses are sometimes not significant for $\mathrm{DG}_{\mathrm{F}}$ and $\mathrm{DG}_{\mathrm{L}}$.

\subsection{Growth models}

The estimated parameters of the Gompertz model are shown in Table 4. Parameter $A$ (estimated mature body weight) was more or less constant for all crosses. Only for $\mathrm{CH}$ is the es- timated mature body weight significantly lower compared to the other crosses. Parameter $B$ (maximum daily gain) and $C$ (age at maximum daily gain) showed more variability between the six crosses. The numerically highest $B$ value was estimated for IF and the lowest for ML. Lowest $C$ value was observed for $\mathrm{CH}$ and highest for SU. Males and twins (Table 4) compared to females and singletons respectively, showed higher estimated mature body weight. The same holds true for parameter $C$. Maximum daily gain is higher for males and for singletons. The Gompertz model fit the data well, as indicated by the high average $R^{2}$ value of 0.994 and low average MSE of 0.789 .

The results of parameters of the linear model (INT and $b$ ) are shown in Table 5. Both parameters varied significantly across the crosses. The lowest birth weight (parameter INT) was estimated for SU and SK and the highest for $\mathrm{CH}$ and TX. The highest average daily gain (parameter $b$ ) was estimated for IF and the lowest for ML. Males and twins in particular showed lower estimated birth weights (Table 5). Males also showed a higher estimated DG; the same holds true for singletons. The goodness of fit of the model was also high with an average $R^{2}$ value of 0.987 and average MSE of 1.521. However, the fit was slightly poorer than the fit of the Gompertz model, which becomes especially obvious when comparing the MSE of both models.

\section{Discussion}

First of all, the weakness of the experimental design has to be acknowledged. It was not possible to include more rams per sire breed because there were no additional progeny tested sires available. In addition, it would have been better to house all lambs in individual pens, which was however not possible due to the limited test capacity on the research farm.

\subsection{Describing parameters at birth, weaning and finishing}

The low range of BW and age at weaning across the crosses (Table 1) indicate that there were no big differences in growth 
Table 3. Effect of cross on FCR, eFCR, DG during the fattening period and over the lifetime of fattening lambs.

\begin{tabular}{|c|c|c|c|c|c|c|c|c|}
\hline \multirow[t]{2}{*}{ Cross } & \multicolumn{2}{|c|}{$\mathrm{FCR}, \mathrm{kg} \mathrm{DM} \mathrm{kg}^{-1}$} & \multicolumn{2}{|c|}{ eFCR, MJ ME kg ${ }^{-1 *}$} & \multicolumn{2}{|c|}{$\mathrm{DG}_{\mathrm{F}}^{* *}$} & \multicolumn{2}{|c|}{$\mathrm{DG}_{\mathrm{L}}^{* * *}$} \\
\hline & Mean & SE & Mean & SE & LS mean & SE & LS mean & SE \\
\hline $\mathrm{CH}$ & $5.5^{\mathrm{d}}$ & 0.2 & $63.2^{c}$ & 2.0 & $297.4^{\mathrm{c}}$ & 7.2 & $298.7^{\mathrm{cd}}$ & 6.1 \\
\hline IF & $4.5^{\mathrm{a}}$ & 0.1 & $51.2^{\mathrm{a}}$ & 1.5 & $374.1^{\mathrm{a}}$ & 8.9 & $345.3^{\mathrm{a}}$ & 7.5 \\
\hline ML & $5.0^{\mathrm{c}}$ & 0.1 & $55.8^{\mathrm{b}}$ & 1.5 & $294.0^{\mathrm{c}}$ & 7.1 & $288.5^{\mathrm{d}}$ & 5.9 \\
\hline SK & $4.6^{\mathrm{b}}$ & 0.2 & $52.6^{\mathrm{ab}}$ & 1.8 & $329.2^{\mathrm{b}}$ & 8.7 & $312.8^{b c}$ & 7.3 \\
\hline SU & $4.9^{c}$ & 0.1 & $54.5^{\mathrm{ab}}$ & 0.8 & $338.1^{b}$ & 7.4 & $313.5^{b c}$ & 6.1 \\
\hline $\mathrm{TX}$ & $4.5^{\mathrm{a}}$ & 0.2 & $50.7^{\mathrm{a}}$ & 1.8 & $350.3^{\mathrm{ab}}$ & 8.7 & $322.1^{b}$ & 7.3 \\
\hline
\end{tabular}

* MJ ME $=$ megajoule metabolisable energy, ${ }^{* *}$ results from model (1) effect of the sire breed $P<0.0001$, ${ }^{* * *}$ results from model (1) effect of the sire breed $P<0.0001$, abcd Within a column values with different superscript letters (a-d) differ significantly at $P \leq 0.05$.

before the fattening period started. Also, the finishing weight, which is highly dependent on the decisions of the producer or responsible scientist, did not show much variance. In contrast, differences were found in finishing age, which indicates an influence of cross on the age of lamb reaching slaughter weight.

\subsection{Feed conversion and growth performance}

There are significant differences in feed intake (Table 2). Higher feed intake indicates a higher potential of nutrient intake. This might be an advantage under extensive conditions because a lower energy content of the feed can be compensated for by a higher amount of consumed feed. IF and TX seem to have the highest growth potential because they showed highest $\mathrm{DG}_{\mathrm{F}}$ and $\mathrm{DG}_{\mathrm{L}}$. The daily body weight gain during the fattening period of purebred male individuals of meat breeds and ML under similar conditions were reported to be higher in other studies than found in this study (Table 3). Engelhart and Eckl (2012), who considered only purebred male lambs, reported a $\mathrm{DG}_{\mathrm{F}}$ of $362 \mathrm{~g} \mathrm{day}^{-1}$ for Texel, $438 \mathrm{~g} \mathrm{day}^{-1}$ for ML, $445 \mathrm{~g} \mathrm{day}^{-1}$ for German black-headed mutton sheep, $458 \mathrm{~g} \mathrm{day}^{-1}$ for Ile de France, and $468 \mathrm{~g} \mathrm{day}^{-1}$ Suffolk. Bildungs- und Wissenszentrum Aulendorf (2005) reported a $\mathrm{DG}_{\mathrm{F}}$ of $360 \mathrm{~g} \mathrm{day}^{-1}$ for $\mathrm{ML}$ and $\mathrm{CH}, 359 \mathrm{~g} \mathrm{day}^{-1}$ for TX and $409 \mathrm{~g} \mathrm{day}^{-1}$ for SU.

Depending on the diet and breed, different FCR for sheep have been reported in the literature, e.g. 8.8 to $17.8 \mathrm{~kg}$ feed perkg bodyweight gain for different selection lines of Merino and different diets (6.3 to $9.2 \mathrm{MJ} \mathrm{ME} \mathrm{kg}^{-1} \mathrm{DM}$ ) (Doyle et al., 2011). Fahmy et al. (1992) determined FCR of 4.99 to $5.76 \mathrm{~kg} \mathrm{DM} \mathrm{kg}^{-1}$ weight gain for different breeds and crosses including Booroola Merino and Suffolk with feeds of different protein qualities. Engelhart and Eckl (2012) tested purebred male individuals of several meat breed types. The eFCR varied between means of 30.9 for Texel to 32.9 for German black-headed mutton sheep. These figures are below those values found in this study (Table 3), probably because Engelhart and Eckl (2012) considered only purebred male lambs which were expected to be above the mean of a population.

\subsection{Growth models}

As can be seen from the MSE and $R^{2}$, the fit of the Gompertz model was improved compared to the linear model, although both fit the data well. In contrast, Daskiran et al. (2010) reported the best $R^{2}$ results for logistic model. Gbangboche et al. (2008) determined Brody to be the best fitting model, but reported a lower $R^{2}$ for all models than in this study and also used a slightly different Gompertz model. Topal et al. (2004) determined a better fit of the Gompertz model compared to Brody, Logistic and Bertalanffy models for growth of Morkaraman sheep, but for Awassi sheep, the Brody model showed better fit. On the other hand, Yildiz et al. (2009) and Lambe et al. (2006), who used the same model as used in this study, came to the result that the Gompertz model described the growth of their lambs best compared to various other linear and non-linear models.

The good fit of the linear model in our study indicates that individuals used in the dataset were still in the phase of almost linear growth. This is illustrated by the average growth curves fitted to the observed weights (Fig. 1). Observations of older animals are missing and hence the data are truncated. This has implications for the interpretation of the parameters of the Gompertz model. The parameter $A$ usually is interpreted as mature BW. Lambe et al. (2006) used also truncated data from lambs and interpreted the parameter $A$ as finishing weight at the end of fattening. LS means of the Gompertz model parameters are shown in Table 4. Mature BWs of purebred ML are reported to be higher (VDL, 2005) for ML than the estimate of $A$ for ML (Table 4). Hence, parameter $A$ seems to underestimate true mature $\mathrm{BW}$, probably due to the truncated data.

The estimate of parameter $B$ (Table 4), which is interpreted as maximum DG, is higher than the observed average DG (Table 3). This indicates that $B$ might reflect the true maximum DG even though the data were truncated. The low- 
Charollais x Merinolandschaf

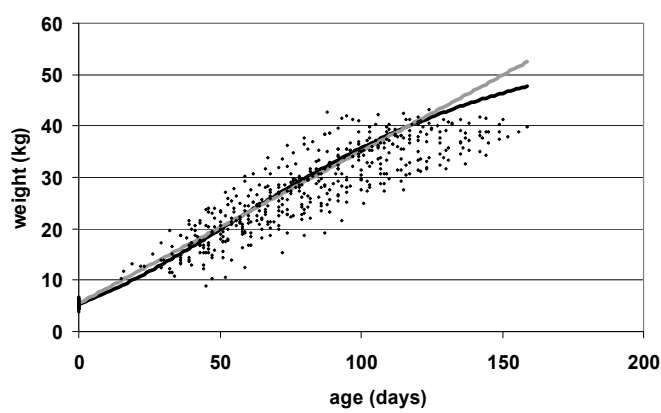

Merinolandschaf $\mathrm{x}$ Merinolandschaf

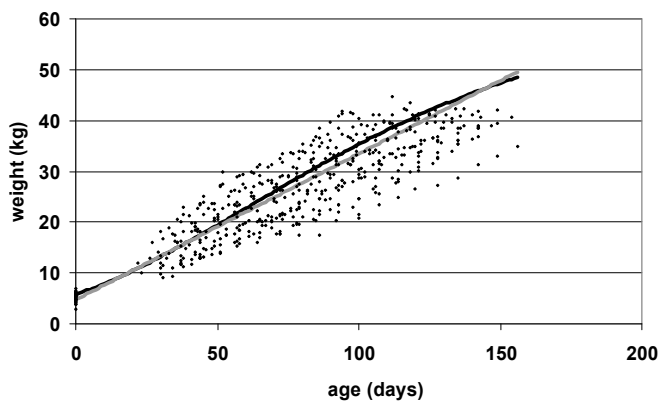

Suffolk $x$ Merinolandschaf

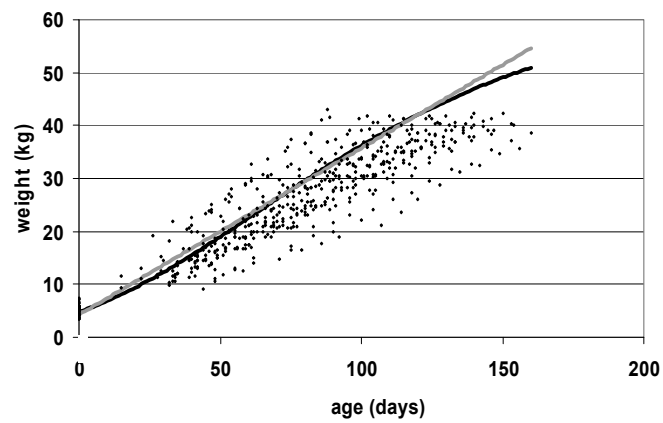

lle de France $\mathrm{x}$ Merinolandschaf

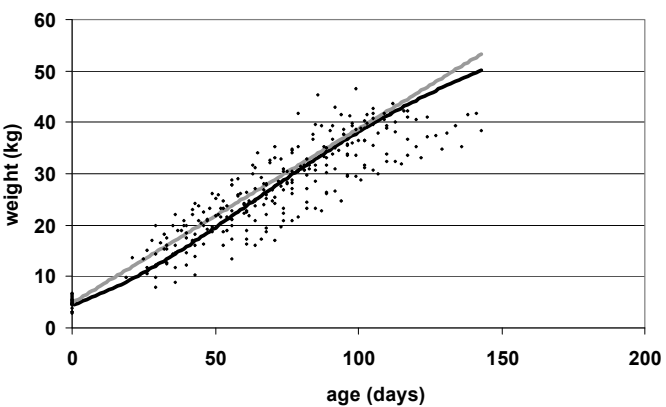

German black-headed mutton sheep x Merinolandschaf

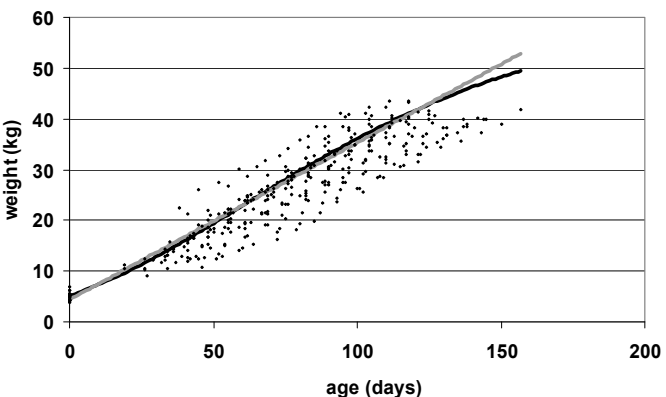

Texel x Merinolandschaf

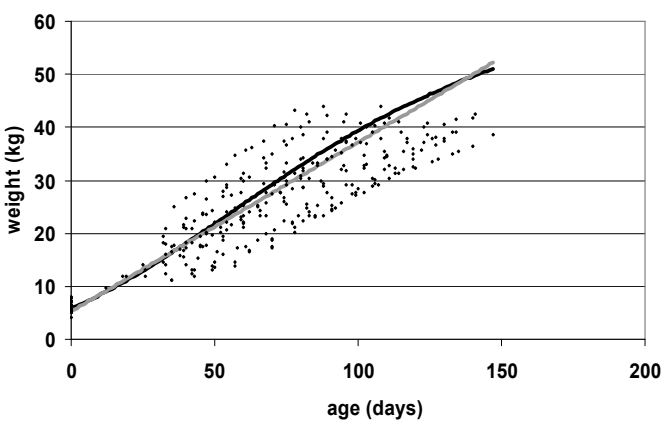

Figure 1. Estimated growth function for Gompertz (black) and linear model (grey) for different crossbred lambs and purebred Merinolandschaf lambs; body weight $(\mathrm{kg})$ plotted against age (days).

est estimate was found for ML. Hence, all crosses were superior in maximum DG compared to ML (although not always significantly).

Parameter $C$, which is interpreted as the age at maximum DG, is the lowest for TX and CH (Table 4). This indicates that TX and especially $\mathrm{CH}$ reached the maximum DG at a younger age compared to the other crosses. This may cause some problems if this maximum DG takes place around weaning. First, because weaning as a stress factor might cause growth depression, sometimes called post-weaning depression (e.g. Peeters et al., 1995). Second, this early maximum DG must be supported by the milk of the ewes. Reduced milk yield of the ewes might result in a reduced maximum DG of the lambs. This is less problematic for lambs that mainly grow later in life during the fattening period, i.e. showing a higher $C$ value (SU and IF in our study, Table 4).

The parameter INT from the linear model underestimates the average birth weight for all crosses except $\mathrm{CH}$ (Tables 1 and 5 and Fig. 1). As expected, the estimated (parameter $b$, Table 5) and observed DG (Table 3) are in close agreement for all crosses.

The influence of sex and birth type on growth in sheep (Tables 4 and 5) was also found by others (Hassen et al., 2002 and Analla et al., 1998, respectively). Daskiran et al. (2010) reported on influences on growth curve parameters. Peeters et al. (1995) not only detected influences on growth, but also on FCR and age of finishing. Additionally, it is well known that males have a higher mature weight than females of the same 
Table 4. Effect of cross, sex and birth type on Gompertz parameters $A$ (estimated mature body weight), $B$ (maximum daily gain) and $C$ (age at maximum daily gain) modelled for fattening lambs.

\begin{tabular}{lll|ll|ll}
\hline Cross/Sex/ & \multicolumn{2}{c|}{$A$} & \multicolumn{2}{c|}{$B$} & \multicolumn{2}{c}{$C$} \\
\cline { 2 - 7 } Birth type & LS mean & SE & LS mean & SE & LS mean & SE \\
\hline CH & $57.4^{\mathrm{b}}$ & 1.6 & $0.340^{\mathrm{cd}}$ & 0.009 & $53.7^{\mathrm{a}}$ & 2.9 \\
IF & $66.2^{\mathrm{a}}$ & 2.6 & $0.387^{\mathrm{a}}$ & 0.012 & $62.6^{\mathrm{ab}}$ & 4.5 \\
ML & $62.8^{\mathrm{a}}$ & 2.0 & $0.329^{\mathrm{d}}$ & 0.009 & $61.2^{\mathrm{ab}}$ & 3.5 \\
SK & $62.2^{\mathrm{a}}$ & 2.0 & $0.349^{\mathrm{bcd}}$ & 0.010 & $60.1^{\mathrm{ab}}$ & 3.6 \\
SU & $64.2^{\mathrm{a}}$ & 1.9 & $0.358^{\mathrm{abc}}$ & 0.009 & $63.1^{\mathrm{b}}$ & 3.4 \\
TX & $64.6^{\mathrm{a}}$ & 2.2 & $0.374^{\mathrm{ab}}$ & 0.011 & $55.4^{\mathrm{ab}}$ & 3.8 \\
Male & $69.3^{\mathrm{a}}$ & 1.8 & $0.391^{\mathrm{a}}$ & 0.006 & $64.3^{\mathrm{a}}$ & 2.7 \\
Female & $56.5^{\mathrm{b}}$ & 0.9 & $0.322^{\mathrm{b}}$ & 0.005 & $54.3^{\mathrm{b}}$ & 1.6 \\
Singleton & $59.8^{\mathrm{a}}$ & 1.2 & $0.370^{\mathrm{a}}$ & 0.006 & $47.0^{\mathrm{a}}$ & 2.1 \\
Twin & $66.0^{\mathrm{b}}$ & 1.3 & $0.342^{\mathrm{b}}$ & 0.006 & $71.6^{\mathrm{b}}$ & 2.3 \\
\hline
\end{tabular}

abcd Within a column values and given the same aspect (cross, sex or birth type), values with different superscript letters $(\mathrm{a}-\mathrm{d})$ differ significantly at $P \leq 0.05$.

Table 5. Effect of cross, sex and birth type on parameters INT and $\mathrm{b}$ of linear regression modelled for fattening lambs.

\begin{tabular}{lll|ll}
\hline Cross/Sex/ & \multicolumn{2}{c|}{ INT } & \multicolumn{2}{c}{$b$} \\
\cline { 2 - 5 } Birth type & LS mean & SE & LS mean & SE \\
\hline CH & $5.8^{\mathrm{c}}$ & 0.2 & $0.296^{\mathrm{ab}}$ & 0.007 \\
$\mathrm{IF}$ & $4.8^{\mathrm{abc}}$ & 0.3 & $0.339^{\mathrm{d}}$ & 0.009 \\
ML & $4.7^{\mathrm{ab}}$ & 0.2 & $0.287^{\mathrm{a}}$ & 0.006 \\
SK & $4.4^{\mathrm{a}}$ & 0.3 & $0.309^{\mathrm{bc}}$ & 0.008 \\
SU & $4.2^{\mathrm{a}}$ & 0.3 & $0.315^{\mathrm{c}}$ & 0.007 \\
TX & $5.2^{\mathrm{bc}}$ & 0.3 & $0.318^{\mathrm{cd}}$ & 0.008 \\
Male & $4.5^{\mathrm{a}}$ & 0.2 & $0.337^{\mathrm{a}}$ & 0.005 \\
Female & $5.2^{\mathrm{b}}$ & 0.1 & $0.284^{\mathrm{b}}$ & 0.004 \\
Singleton & $6.2^{\mathrm{a}}$ & 0.2 & $0.327^{\mathrm{a}}$ & 0.005 \\
Twin & $3.5^{\mathrm{b}}$ & 0.2 & $0.294^{\mathrm{b}}$ & 0.004 \\
\hline
\end{tabular}

abcd Within a column values and given the same aspect (cross, sex or birth type), values with different superscript letters (a-d) differ significantly at $P \leq 0.05$.

breed. As expected, significant differences between sexes and birth types were detected in this study. Mature BW (parameter $A$, Table 4) shows differences between sexes, even though absolute values are underestimated as already discussed above. Males are estimated to be significantly heavier. Estimations for DG ( $B$ and $b$, Tables 4 and 5) were higher for males and singletons compared to females and twins. Female lambs are younger at maximum DG (parameter $C$, Table 5) than males.

In conlusion, IF and TX seem to be of greatest economic interest for intensive fattening because they showed the best FCR and eFCR. Only these crosses were significantly superior compared to purebred ML in FCR, eFCR and also in $\mathrm{DG}_{\mathrm{F}}$. This underlines the advantage of one-way crossbreeding for efficiently producing lamb meat.
Both growth models were well suited to model the data, but the fit of the Gompertz model was slightly better. In addition, the use of the Gompertz model provided some interesting biological insights of the growth of lambs and differences between the crosses, even though the lambs were slaughtered before reaching mature $\mathrm{BW}$.

Acknowledgements. The authors thank the team of the Oberer Lindenhof experimental station of the University of Hohenheim. The study was supported by the Ministerium für ländlichen Raum, Ernährung und Verbraucherschutz Baden-Württemberg (MLR) and the Marketing Gesellschaft Baden-Württemberg (MBW). K. F. Schiller was supported by the H. Wilhelm Schaumann Stiftung, Hamburg, Germany.

Edited by: A.-E. Freifrau von Tiele-Winckler Reviewed by: two anonymous referees

\section{References}

Analla, M., Montilla, J. M., and Serradilla, J. M.: Analyses of lamb weight and ewe litter size in various lines of Spanish Merino sheep, Small Rumin. Res., 29, 255-259, 1998.

Bildungs- und Wissenszentrum Aulendorf: [Test report no. 2 2005: Influence of father race on the fattening performance of lambs], Education and knowledge center Aulendorf, Livestock, vegetation management, wildlife, fisheries, Aulendorf, Germany, 2005 (in German).

Daskiran, I., Koncagul, S., and Bingol, M.: Growth Characteristics of Indigenous Norduz Female and Male Lambs, Tar Bil Der - J. Agric. Sci., 16, 62-69, 2010.

Doyle, E. K., Kahn, L. P., McClure, S. J., and Lea, J. M.: Voluntary feed intake and diet selection of Merino sheep divergently selected for genetic difference in resistance to Haemonchus contortus, Vet. Parasitol., 177, 316-323, 2011.

Engelhart, T. and Eckl, R.: Test Station for sheep St. Johann - 30th Report on the Audit of the fattening performance and carcass value in sheep test year 2011/2012. Main and state stud Marbach, Marbach, Germany, 2012 (in German).

Fahmy, M. H., Boucher, J. M., Poste, L. M., Grégoire, R., Butler, G., and Comeau, J. E.: Feed efficiency, carcass characteristics, and sensory quality of lambs, with or without prolific ancestry, fed diets with different protein supplements, J. Anim. Sci., 70, 1365-1374, 1992.

Gbangboche, A. B., Glele-Kakai, R., Salifou, S., Albuquerque, L. G., and Leroy, P. L.: Comparison of non-linear growth models to describe the growth curve in West African Dwarf sheep, Animal, 2, 1003-1012, 2008.

Hassen, Y., Sölkner, J., Gizaw, S., and Baumung, R.: Performance of crossbred and indigenous sheep under village conditions in the cool highlands of central-northern Ethiopia: growth, birth and body weights, Small Rumin. Res., 43, 195-202, 2002.

Henseler, S., Preuss, S., and Bennewitz, J.: Meat Production with Merinolandschaf Crossbreeds - 1st Communication: Analysis if Carcase and Meat Quality, Züchtungskunde, 86, 95-103, 2014a (in German). 
Henseler, S., Preuss, S., and Bennewitz, J.: Meat Production with Merinolandschaf Crossbreeds - 2nd Communication: Sensory Analysis and Creation of a Joint Index for the Results, Züchtungskunde, 86, 104-115, 2014b (in German).

Lambe, N. R., Navajas, E. A., Simm, G., and Bünger, L.: A genetic investigation of various growth models to describe growth of lambs of two contrasting breeds, J. Anim. Sci., 84, 2642-2654, 2006.

Peeters, R., Kox, G., and Van Isterdael, J.: Environmental and genetic influences on growth performance of lambs in different fattening systems, Small Rumin. Res., 18, 57-67, 1995.

Sambraus, H. H.: Sheep, in: Color atlas of livestock breeds, 7th ed., Stuttgart, Germany, 160-181, 2011 (in German).

Strittmatter, K.: Development, situation and perspectives of the sheep production in Germany, Züchtungskunde, 77, 496-501, 2005 (in German).
Topal, M., Ozdemir, M., Aksakal, V., Yildiz, N., and Dogru, U.: Determination of the best nonlinear function in order to estimate growth in Morkaraman and Awassi lambs, Small Rumin. Res., 55, 229-232, 2004.

VDL: VDL Race and breeding objective description Merino sheep, http://www.bundesverband-schafe.de/uploads/media/ Merinolandschaf_03.pdf (last access: September 2014), 2005 (in German).

Yildiz, G., Soysal, M. I., Gürcan, E. K.: Determination of Growth Curve with Different Model in the Karacabey Merinos x Kıvırc1k Crossbred Lambs Raised in Tekirdağ Provinces, J. Tekirdag Agric. Fac., 6, 11-19, 2009 (in Turkish). 